\title{
max \\ Hydrothermally Grown ZnO Nanostructures for Water Purification via Photocatalysis
}

\author{
Marie Le Pivert ${ }^{1,2}\left(\mathbb{D}\right.$, Nathan Martin ${ }^{1,3}$ and Yamin Leprince-Wang ${ }^{1, *}$ (i) \\ 1 ESYCOM Lab, CNRS, University Gustave Eiffel, 77454 Marne-la-Vallee, France; \\ marie.le-pivert@univ-eiffel.fr (M.L.P.); nathan.martin@univ-eiffel.fr (N.M.) \\ 2 COSYS-LISIS Lab, University Gustave Eiffel, 77454 Marne-la-Vallee, France \\ 3 Eden Tech, 75012 Paris, France \\ * Correspondence: yamin.leprince@univ-eiffel.fr
}

Citation: Le Pivert, M.; Martin, N.; Leprince-Wang, Y. Hydrothermally Grown ZnO Nanostructures for Water Purification via Photocatalysis. Crystals 2022, 12, 308. https:// doi.org/10.3390/cryst12030308

Academic Editor: Claudia Graiff

Received: 4 February 2022

Accepted: 19 February 2022

Published: 22 February 2022

Publisher's Note: MDPI stays neutral with regard to jurisdictional claims in published maps and institutional affiliations.

Copyright: (C) 2022 by the authors. Licensee MDPI, Basel, Switzerland. This article is an open access article distributed under the terms and conditions of the Creative Commons Attribution (CC BY) license (https:// creativecommons.org/licenses/by/ $4.0 /)$.

\begin{abstract}
Semiconductor-based photocatalysis is a well-known and efficient process for achieving water depollution with very limited rejects in the environment. Zinc oxide ( $\mathrm{ZnO})$, as a wide-bandgap metallic oxide, is an excellent photocatalyst, able to mineralize a large scale of organic pollutants in water, under UV irradiation, that can be enlarged to visible range by doping nontoxic elements such as $\mathrm{Ag}$ and $\mathrm{Fe}$. With high surface/volume ratio, the $\mathrm{ZnO}$ nanostructures have been shown to be prominent photocatalyst candidates with enhanced photocatalytic efficiency, owing to their being low-cost, non-toxic, and able to be produced with easy and controllable synthesis. Thus, $\mathrm{ZnO}$ nanostructures-based photocatalysis can be considered as an eco-friendly and sustainable process. This paper presents the photocatalytic activity of $\mathrm{ZnO}$ nanostructures (NSs) grown on different substrates. The photocatalysis has been carried out both under classic mode and microfluidic mode. All tests show the notable photocatalytic efficiency of ZnO NSs with remarkable results obtained from a ZnO-NSs-integrated microfluidic reactor, which exhibited an important enhancement of photocatalytic activity by drastically reducing the photodegradation time. UV-visible spectrometry and high-performance liquid chromatography, coupled with mass spectrometry (HPLC-MS), are simultaneously used to follow real-time information, revealing both the photodegradation efficiency and the degradation mechanism of the organic dye methylene blue.
\end{abstract}

Keywords: $\mathrm{ZnO}$ nanostructures; hydrothermal synthesis; $\mathrm{ZnO}$ doping; photocatalysis; water purification; degradation mechanism study

\section{Introduction}

The management of water resources is a continually growing issue, impacting human health, climate change and the global economy [1]. Unfortunately, water pollution problems, notably caused by various dyes originating from the textile, pharmaceutical and food-processing industries, increase at the same time. For this reason, water quality and treatment were set at the top of societal priority action list [2] to find efficient, low-cost, and environmentally friendly purification processes, leading to a huge increase in the research on this topic. Among all the solutions, photocatalytic oxidative processes appeared as promising air and water purification methods due to their ability to degrade and mineralize toxic organic pollutants into harmless compounds such as $\mathrm{H}_{2} \mathrm{O}, \mathrm{CO}_{2}, \mathrm{NO}_{3}{ }^{-}$. . by using only a light source and a photocatalyst $[3,4]$.

To produce highly efficient materials for water remediation, a variety of photocatalysts and synthesis methods have been developed [5-11]. Nevertheless, even among them, some solutions are using complex, expensive, and energy-consuming production processes. Furthermore, some of the synthesis processes, although efficient, lead to non-eco-friendly photocatalysts. In order to develop new photocatalytic materials, it is therefore needed to use eco-friendly photocatalysts, synthesized with a low-cost method, by using the 
least chemical products possible and employing the shortest possible fabrication period. Moreover, photocatalyst synthesis must be universal to a large kind of support in order to be developed at different scales, and to be usable by different solutions.

Among the different existing options of photocatalysts, zinc oxide nanostructures ( $\mathrm{nnO}$ NSs) have been selected for their ease of growth using soft chemistry conditions. Moreover, $\mathrm{ZnO}$ NSs have already shown great potential as eco-friendly photocatalysts for environmental pollution remediation under UV or solar light [12-14]. Besides, ZnO is a multifunctional material with for instance piezo-electric properties, which could improve photocatalysis efficiency [15]. ZnO NSs also present the advantages of being low-cost photocatalysts, whose raw materials are abundant in nature [4], and which could be produced by soft chemical methods, at low temperature, and with a reduced need for dangerous chemical compounds. The easy-to-perform method of the hydrothermal synthesis only requires a low processing temperature $\left(\leq 100^{\circ} \mathrm{C}\right)$ and a short duration $(\leq 4 \mathrm{~h})$, and could be easily scaled-up and adapted to different substrates $[12,15,16]$.

This paper gives an overview of our previous works on the development of different ZnO-NSs-based materials by hydrothermal synthesis and their photocatalytic activity for water purification. The universality and feasibility of this production will be presented on various substrates, from wafer silicon (Si) substrates to civil engineering materials, and from the classic synthesis in an autoclave reactor to an in situ synthesis in microfluidic cells. Different strategies to reduce the $\mathrm{ZnO}$ band gap and improve its photocatalytic efficiency will also be introduced. Then, this paper will display photocatalytic results under classic mode and microfluidic mode, both under UV light and solar light. Furthermore, this paper will investigate the photodegradation mechanisms of two organic dyes, methylene blue (MB) and Acid Red 14 (AR14), by UV-visible spectrometry (UV-vis) and high-performance liquid chromatography, coupled with mass spectrometry (HPLC-MS).

\section{ZnO Nanostructures Grown by Hydrothermal Synthesis and Strategies to Improve Their Photocatalytic Activity}

Usually, hydrothermal synthesis allows the ZnO NSs growth onto different substrates by two simple operating steps: (1) a $\mathrm{ZnO}$ seed layer deposition for creating nucleation sites on the substrate to act as nucleation centers to promote the homogeneous growth of the ZnO NS. This step also allows a better control on the morphology and density of the $\mathrm{ZnO}$ NSs in the second step; (2) a hydrothermal growth in presence of zinc salt and hexamethylenetetramine (HMTA) to obtain nanowires (NWs) or nanorods (NRs) following the growth mechanism presented in the Equations (1)-(5) [9,17-19]. During step 2, the ZnO NWs and NRs growth follows the (002) plan to minimize the surface energy [20]. Indeed, $\mathrm{ZnO}$ polar faces have higher energy than the non-polar ones.

$$
\begin{gathered}
\left(\mathrm{CH}_{2}\right)_{6} \mathrm{~N}_{4}+6 \mathrm{H}_{2} \mathrm{O} \rightarrow 6 \mathrm{HCHO}+4 \mathrm{NH}_{3} \\
\mathrm{NH}_{3}+\mathrm{H}_{2} \mathrm{O} \rightarrow \mathrm{OH}^{-}+\mathrm{NH}_{4}^{+} \\
\mathrm{Zn}^{2+}+4 \mathrm{OH}^{-} \rightarrow \mathrm{Zn}(\mathrm{OH})_{4}^{2-} \rightarrow \mathrm{ZnO}+2 \mathrm{OH}^{-}+\mathrm{H}_{2} \mathrm{O} \\
\mathrm{Zn}\left(\mathrm{NH}_{3}\right)_{4}^{3+}+2 \mathrm{OH}^{-} \rightarrow \mathrm{ZnO}+4 \mathrm{NH}_{3}+\mathrm{H}_{2} \mathrm{O} \\
\mathrm{Zn}^{2+}+2 \mathrm{OH}^{-} \rightarrow \mathrm{Zn}(\mathrm{OH})_{2} \stackrel{\Delta}{\rightarrow} \mathrm{ZnO}+\mathrm{H}_{2} \mathrm{O}
\end{gathered}
$$

This section presents the adaptation of this process to different substrates and the main proofs of the good synthesis of ZnO NSs. The development of the synthesis at different scales with different modes and the strategies to improve photocatalytic activity are also introduced.

\subsection{Silicon Functionalization}

Si functionalization has been a well-designed synthesis for years now. The seed layer deposition commonly consists of a spin-coating (1 min, $3000 \mathrm{rpm}$ ) of the Si substrate with a 
buffer layer of polyvinyl alcohol (PVA, $10 \mathrm{~g})$ and zinc acetate dihydrate $\left(\mathrm{Zn}(\mathrm{Ac})_{2} \cdot 2 \mathrm{H}_{2} \mathrm{O}\right.$, $1 \mathrm{~g})$ in water $(500 \mathrm{~mL})$. Then, the deposited thin film is calcined at $500{ }^{\circ} \mathrm{C}$ for $3 \mathrm{~h}$ in ambient atmosphere to remove the PVA and form $\mathrm{ZnO}$ nanocrystallites as seeds. The growing process of $\mathrm{ZnO} N W s$ is finally achieved at $90{ }^{\circ} \mathrm{C}$ during $4 \mathrm{~h}$ into a sealed Teflon reactor containing an aqueous solution of zinc nitrate hexahydrate $\left(\mathrm{Zn}\left(\mathrm{NO}_{3}\right)_{2} \cdot 6 \mathrm{H}_{2} \mathrm{O}\right)$ and HMTA. By playing with the concentration, the morphology and the defect concentration in the $\mathrm{ZnO}$ band gap could be tuned (Figure 1) [20,21]. It is noteworthy to mention that our results presented in Figure 1 are in line with literature [20,21].

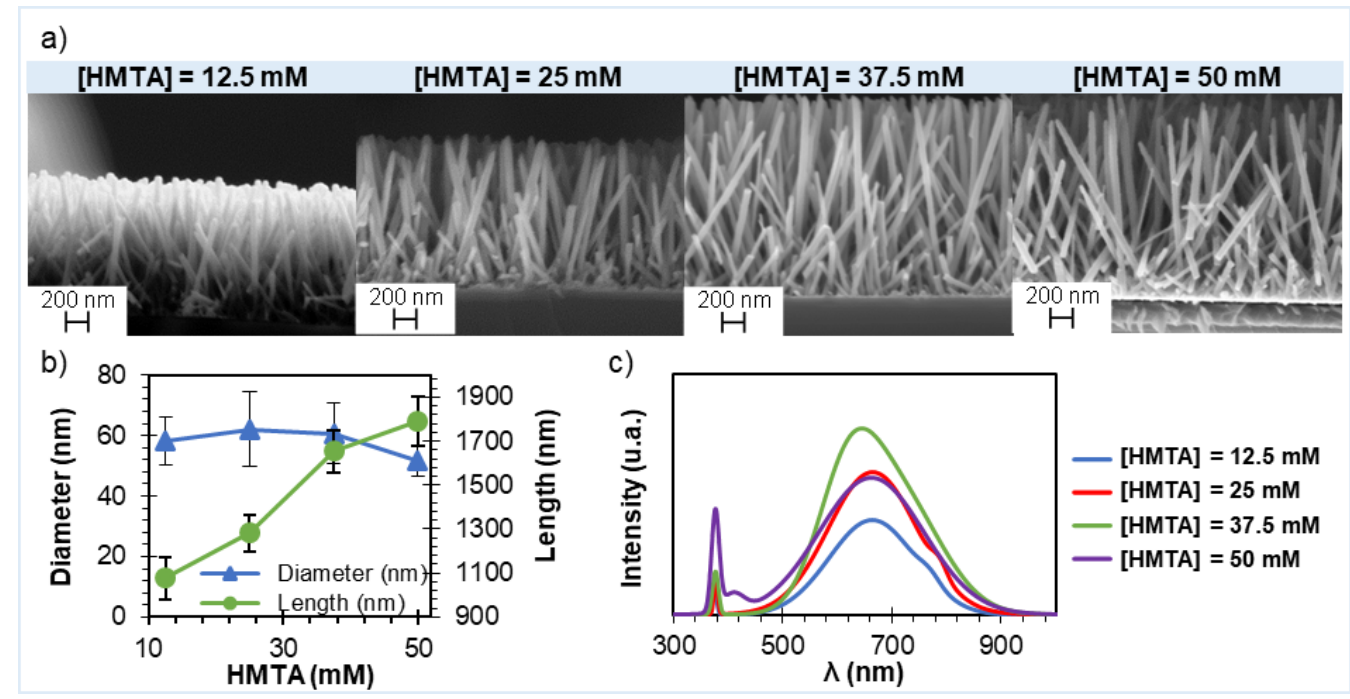

Figure 1. (a) SEM images, (b) diameter and length, and (c) photoluminescence characterization of $\mathrm{ZnO} N W$ s grown at fixed $\mathrm{Zn}\left(\mathrm{NO}_{3}\right)_{2}$ concentration of $0.05 \mathrm{M}$ and variable HMTA concentration and post-annealed at $500{ }^{\circ} \mathrm{C}$.

In our previous work, two concentration conditions were selected depending on the NWs wanted morphology (ratio diameter vs. length) and defect concentration: (1) $75 \mathrm{mM}$ of $\mathrm{Zn}\left(\mathrm{NO}_{3}\right)_{2}$ and $37.5 \mathrm{mM}$ of HMTA, corresponding to a growth solution with $37.5 \mathrm{mM}$ of $\mathrm{Zn}\left(\mathrm{NO}_{3}\right)_{2}$ and $18.75 \mathrm{mM}$ of HMTA (C1); (2) $50 \mathrm{mM}$ of $\mathrm{Zn}\left(\mathrm{NO}_{3}\right)_{2}$ and $50 \mathrm{mM}$ of HMTA corresponding to an equimolar growth solution at $25 \mathrm{mM}$ (C2) [22-24]. At the end of the growing process, the Si substrates covered by $\mathrm{ZnO}$ NWs were washed with DI water, dried under hot airflow $\left(\sim 30 \mathrm{~s}\right.$ at $\left.\sim 53{ }^{\circ} \mathrm{C}\right)$, and post-annealed in an oven at $350{ }^{\circ} \mathrm{C}$ for $30 \mathrm{~min}$ in ambient atmosphere to improve the $\mathrm{ZnO}$ crystallinity. Scanning electron microscope images (SEM, Zeiss FE-SEM NEON 40, Iéna, Germany) demonstrated that well organized and homogeneous $\mathrm{ZnO}$ NWs grown onto $\mathrm{Si}\left(1.55 \mathrm{~cm}^{2}\right)$ were obtained, with a measured height of $1.10 \pm 0.05 \mu \mathrm{m}$ and a measured mean diameter of $85 \pm 5 \mathrm{~nm}$ in concentration conditions (C1) and a measured height of $1.80 \pm 0.1 \mu \mathrm{m}$ and a measured mean diameter of $51 \pm 5 \mathrm{~nm}$ in concentration conditions (C2) [24,25]. Previous characterization works also proved the good crystallinity of the as-obtained ZnO NWs by ultraviolet-visible spectrophotometry (Maya2000 Pro from Ocean Optics, Dunedin, FL, USA), with a mean measured gap value around $3.21 \pm 0.03 \mathrm{eV}$, and by X-ray diffraction (XRD, CuK $\alpha, \lambda=1.5418 \AA$, Rigaku Smartlab, Neu-Isenburg, Germany), with ZnO Wurtzite peaks obtention [22-25].

\subsection{Engineering Materials Functionalization}

The synthesis method presented in Section 2.1 proved its efficiency not only on silicon (Figure 2a), but also on other substrates such as quartz glass [26,27]. However, depending on the used substrate, this synthesis must be adapted-notably, the seed layer deposition step. Indeed, the annealing at $500{ }^{\circ} \mathrm{C}$ degree could damage several kinds of samples, such as building construction materials. To overcome this problem, the seed layer buffer solution of PVA deposition by spin-coating was replaced by a horizontal impregnation with 
a $\mathrm{Zn}(\mathrm{Ac})_{2}$ ethanolic solution $(0.01 \mathrm{M})$. This new deposition method led to a shorter and softer annealing at $350^{\circ} \mathrm{C}$ during 30 min only (Figure 2b) [28]. In short, a $\mathrm{ZnO}$ seed layer was deposited on engineering materials, such as tiling, concrete, and rocks aggregate, by a "horizontal impregnation" method with the zinc acetate ethanolic solution, followed by an annealing at $350{ }^{\circ} \mathrm{C}$ for $30 \mathrm{~min}$. Then, a classical hydrothermal growth using equimolar aqueous solutions of HMTA and $\mathrm{Zn}\left(\mathrm{NO}_{3}\right)_{2}$ or $\mathrm{Zn}(\mathrm{Ac})_{2}$ at $0.025 \mathrm{M}$ was carried out in an autoclave at $90{ }^{\circ} \mathrm{C}$. According to our previous work about the optimal growth conditions depending on the used substrate [29], $2 \mathrm{~h}$ was selected as an optimal growth duration for tiling or rock aggregate substrates, and $1 \mathrm{~h} 30 \mathrm{~min}$ for concrete substrates. Finally, the as-synthesized samples were annealed for $30 \mathrm{~min}$ at $350{ }^{\circ} \mathrm{C}$ to remove all the potential residues from the synthesis process and to improve the $\mathrm{ZnO} \mathrm{NSs}$ crystallinity.
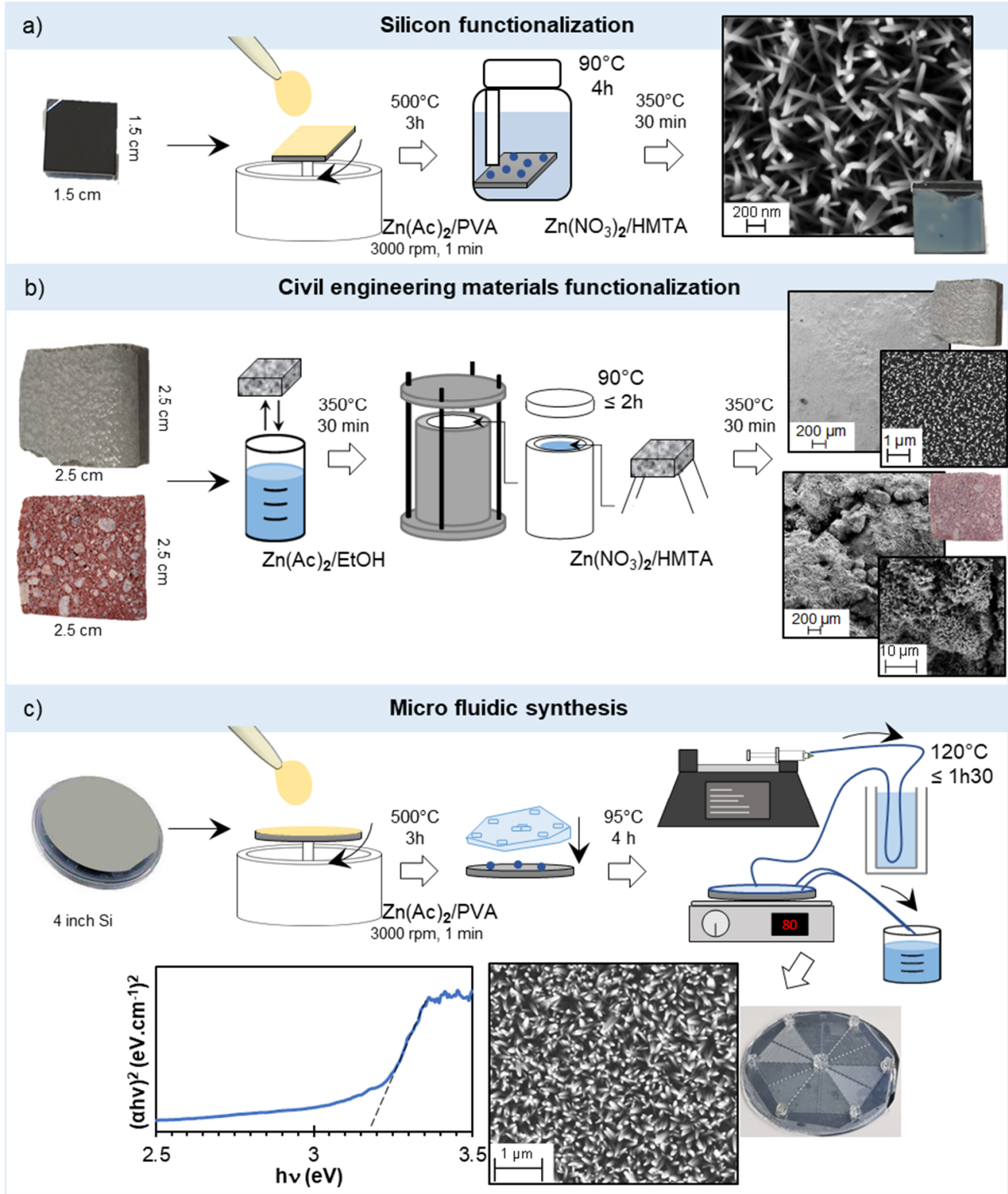

Figure 2. Experimental set-up schema of different developed ZnO NSs synthesis from silicon functionalization (a) and civil engineering materials functionalization (b) to micro fluidic reactor production (c) and obtained SEM images.

Results demonstrated that this hydrothermal synthesis method allowed us to grow $\mathrm{ZnO}$ NSs directly on non-conventional substrates such as tiling and concrete $\left(6.25 \mathrm{~cm}^{2}\right)$. 
Tiling samples showed NSs similar to ZnO NWs grown onto silicon in terms of morphology $(\sim 55 \pm 17 \mathrm{~nm})$, gap value $(\sim 3.20 \pm 0.03 \mathrm{eV})$, and XRD pattern [28,29]. Conversely, a huge discrepancy was recorded on the morphologies of the $\mathrm{ZnO}$ NSs synthesized on concrete substrates. Depending on the growth time ( $1 \mathrm{~h} 30 \mathrm{~min}$ to $4 \mathrm{~h}$ ), NSs vary from complex $\mathrm{ZnO}$ nanosheet structures with a lower gap value $(\sim 3.11 \pm 0.04 \mathrm{eV})$ to NWs and NRs with a gap value of $(\sim 3.17 \pm 0.04 \mathrm{eV})$ [29]. This might be due to a possible influence of the basic surface $\mathrm{pH}$ value and the complex chemical composition of concrete. NSs growth could be also influenced by the textural properties (porosity, roughness, etc.) of concrete and local micro-turbulences [28-30]. The band gap variation could be caused by the morphological modifications of $\mathrm{ZnO}$ NSs, and could also be associated with their crystal quality, dislocations density, impurities, size, and thickness [30-32]. Indeed, nanosheets are supposed to contain more oxygen defects, which could reduce the band gap by acting as indirect donor energy levels below the conduction band [33-35]. Finally, the feasibility of the upscaling of this process was proved by going from a reactor containing $250 \mathrm{~mL}$ of growth solution and a single sample production $\left(6.25 \mathrm{~cm}^{2}\right)$ to a reactor with $8 \mathrm{~L}$ of growth solution with 3 samples per synthesis, without any modification of the ZnO NSs properties $\left(210.25 \mathrm{~cm}^{2}\right)$ [12].

\subsection{Microfluidic Reactor Production}

In the same way as the ease of the scale up, the ease of transposing this hydrothermal synthesis method to the microfluidic mode was proved [30,36]. In order to change from laboratory scale to industrial scale, it is natural to consider going from batch experiments to continuous degradation. Integrating our NSs in a microreactor allows performing this change while avoiding scale-up issues in the synthesis, such as increasing the synthesis reactor size or consuming more growth solution. Furthermore, performing the photocatalytic degradation at microfluidic scale presents several advantages compared to the mesoor macro-fluidic scales: the reduced size of the channels increases the contact between the photocatalyst and the organic pollutants, while diminishing the quantity of light absorbed by the liquid. This is especially important when trying to degrade compounds that absorb the same wavelength as the photocatalyst, or compounds that tend to block the light, as industrial dyes. The continuous stream of liquid to be degraded, combined with the size of the channels, also leads to a situation where the mass transfer of the pollutants is no longer limiting the reaction kinetics, improving the reaction rate [37-40]. All these advantages lead to a generally faster reaction, meaning a higher photocatalytic efficiency than in bigger reactors.

However, one of the major drawbacks of microfluidic reactors is the small flowrate they can deliver, often in the range of $1 \mathrm{~mL} \cdot \mathrm{min}^{-1}$, and the large pressure losses in the microchannels, leading to reactors needing either high pressure at their inlets to ensure the circulation of the liquid, or the consumption of energy to make the liquid flow. To circumvent these problems, the start-up Eden Tech developed a microreactor with a weblike design, allowing higher flowrates with lower pressure losses. This microreactor design is thermally pressed into a Flexdym ${ }^{\mathrm{TM}}$ (a thermoset compound created by Eden Tech [41]) chip at $165^{\circ} \mathrm{C}$ during $760 \mathrm{~s}$ to create the superior part of the microreactor. The other part of the reactor consists of a circular 4 inches $\mathrm{Si}$ wafer, onto which a seed-layer solution has been deposited following the spin-coating process shown in part 2.1 (Figure 2c). The two parts of the microreactor are then bonded together in an oven at $120^{\circ} \mathrm{C}$ during $4 \mathrm{~h}$. After these two steps, the synthesis per se takes place: the growth solution, a volume balance mix of a solution of $\mathrm{Zn}\left(\mathrm{NO}_{3}\right)_{2}$ at $75 \mathrm{mM}$ and a solution of HMTA at $37.5 \mathrm{mM}$, is continuously injected into a double-layer beaker where it is heated to the desired temperature before entering the microreactor, filling the channels, before exiting the microreactor. The functionalized microreactor obtained at the end of the production process is pictured in Figure 3. Playing with the solution flowrate (from $100 \mu \mathrm{L} \cdot \mathrm{min}^{-1}$ to $400 \mu \mathrm{L} \cdot \mathrm{min}^{-1}$ ), the solution temperature (from $80^{\circ} \mathrm{C}$ to $90^{\circ} \mathrm{C}$ ) and the growth time (from $30 \mathrm{~min}$ to $1 \mathrm{~h} 30 \mathrm{~min}$ ) leads to changes in 
the $\mathrm{ZnO}$ NWs morphology and density, resulting in huge differences in their photocatalytic efficiency, as shown in our previous work [30].

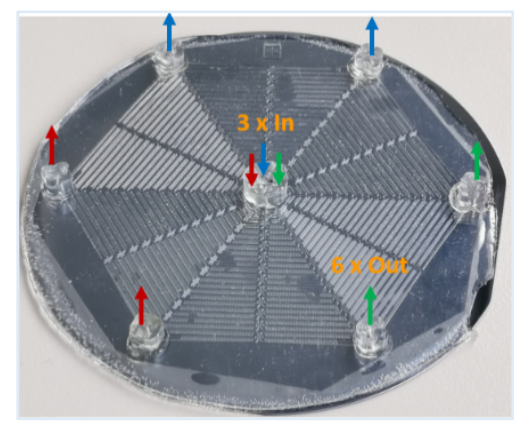

Figure 3. Picture of the final microreactor produced according to our method. The inlets (in the center) and outlets (at the edge) of the reactor are highlighted in color.

The best results, in terms of their photocatalytic efficiency, were obtained with the following parameters: a flowrate of $200 \mu \mathrm{L} \cdot \mathrm{min}^{-1}$, a solution temperature of $80{ }^{\circ} \mathrm{C}$ and a growth time of $1 \mathrm{~h}$. Those parameters allow the growth of $\mathrm{ZnO}$ NWs with a mean diameter of $58 \pm 5 \mathrm{~nm}$ and a mean density of $64 \pm 5 \mathrm{NWs} / \mu \mathrm{m}^{2}$. Increasing the temperature or the flowrate leads to the creation of aggregates and zones devoid from NSs in the microchannels, whereas decreasing the flowrate means smaller NWs diameter and density. Changing the growth time still leads to the NWs obtaining, but has an effect on their density and mean diameter, and, thus, on their photocatalytic efficiency [30].

The effect of the flowrate on the NSs is linked to the availability of the precursors in the solution: when the flowrate is too low (i.e., under $100 \mu \mathrm{L} \cdot \mathrm{min}^{-1}$ ), the precursors are not regenerated quickly enough compared to the reaction kinetics, leading to a limited total reaction rate, and as such, less and smaller NWs in the same reaction time. On the other hand, when the flowrate increases too much (above $200 \mu \mathrm{L} \cdot \mathrm{min}^{-1}$ ), the size of the depletion layer, defined as the layer in the flow above the bottom of the samples, where there is no precursor, as they are consumed by the reaction, decreases. This means that the precursors are more available for the reaction, promoting the NWs growth and their agglomeration into big clusters [30].

When the temperature increases above $80^{\circ} \mathrm{C}$, the solubility of the gases in the solution diminishes. As the $\mathrm{ZnO}$ growth reaction produces $\mathrm{NH}_{3}$ (see Equation (4)), this leads to the apparition of gas bubbles in the microchannels, creating zones where the liquid does not flow, and where the reaction cannot take place. Combined with the augmentation of the reaction rate with the temperature, this causes the apparition of zones devoid from any NSs, and zones where the NSs agglomerate and form clusters [30].

Finally, the effect of the growth time is simply linked to the reaction kinetics: a smaller growth time leads to smaller and less dense NWs, and a higher growth time leads to bigger and more dense NWs [30]. The effect of the different growth conditions on the NSs was measured thanks to SEM observations. The obtained images for each of the different growth conditions are summarized in Figure 4. 
a)

Effect of the flowrate
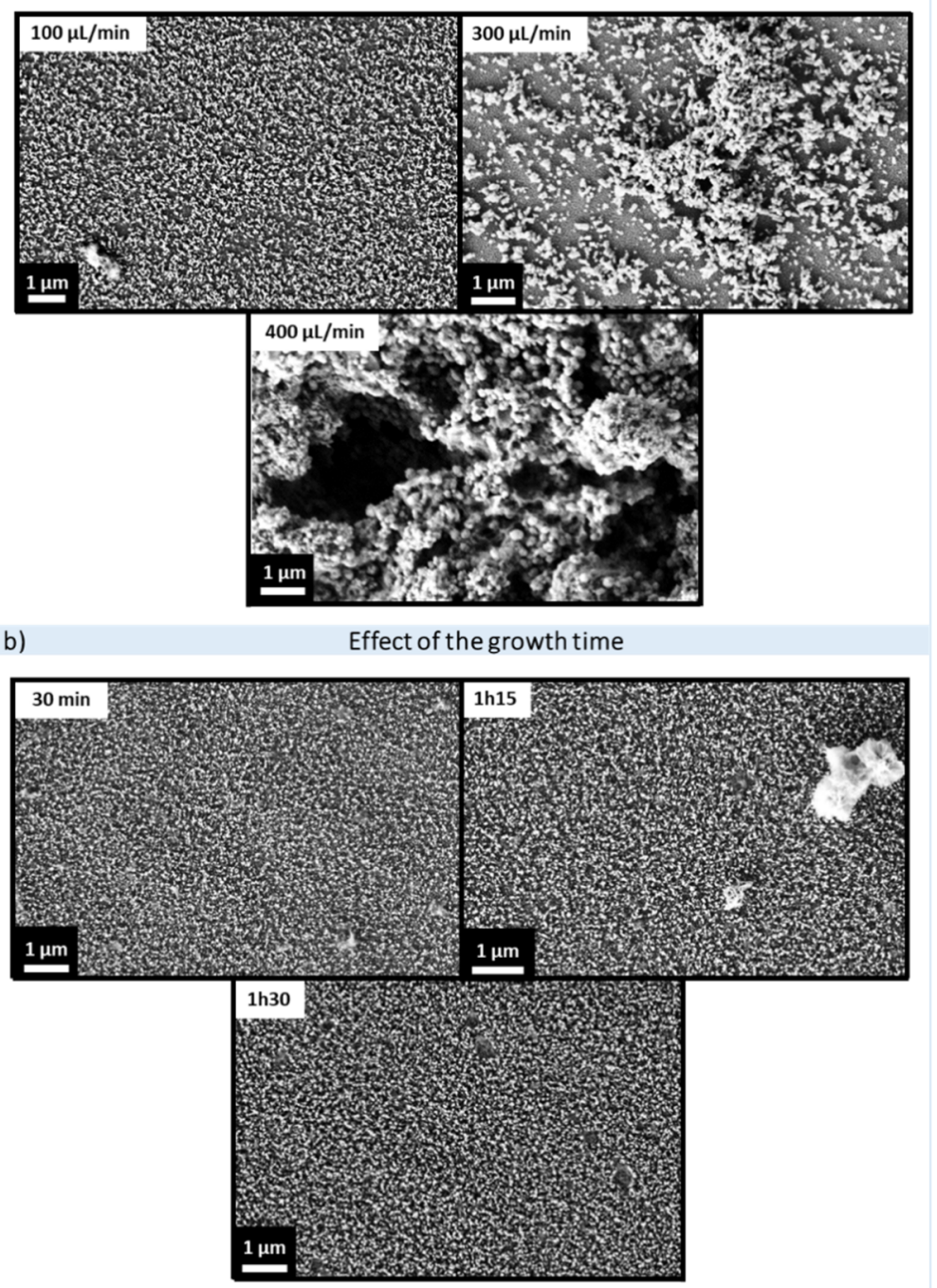

c)

Effect of the growth temperature

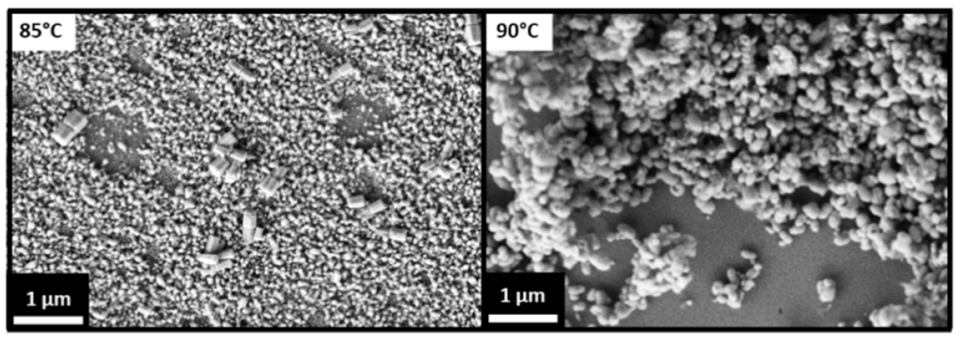

d) Results obtained in the best growth conditions $\left(200 \mu \mathrm{L} / \mathrm{min}, 1 \mathrm{~h}, 80^{\circ} \mathrm{C}\right)$

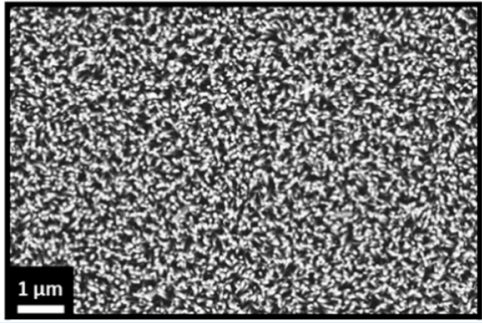

Figure 4. SEM images of the $\mathrm{ZnO} \mathrm{NWs}$ obtained in the microreactor depending on the different growth conditions: effect of flowrate (a), effect of growth time (b), effect of the growth temperature (c) and the best growth conditions: $200 \mu \mathrm{L} / \mathrm{min}, 1 \mathrm{~h}, 80^{\circ} \mathrm{C}$ (d) (reproduced from [30] with permission of the Royal Society of Chemistry). 


\subsection{ZnO Photocatalytic Activity Improvement Strategies}

As a large band gap semiconductor, $\mathrm{ZnO}$ is particularly interesting as a stable photocatalyst with appropriate band-level potential energy to oxidize water and reduce oxygen, to provide radicals for the photocatalytic degradation of organic pollutants. Nevertheless, in view of an application under natural sunlight, extending the $\mathrm{ZnO}$ light absorption will be necessary. Indeed, $\mathrm{ZnO}$ is only able to absorb $~ 5 \%$ of natural sunlight, which corresponds to UV light. Increasing the quantity of light that the samples are able to absorb would help accelerate the photocatalytic reaction, and so, increase their photocatalytic efficiency. Another objective is to maximize the lifetime of the photo-generated electron-hole pairs, as this will increase their chances of producing the radicals needed by the reaction. Thus, until now, many strategies were developed to improve the $\mathrm{ZnO}$ light absorption, such as playing on the synthesis parameters and oxygen defects in the structure [42,43], by introducing non-metallic ions such as carbon $(\mathrm{C})$, nitrogen $(\mathrm{N})$, fluorine $(\mathrm{F})[4]$ or metallic ions, such as iron $(\mathrm{Fe})$, lead $(\mathrm{Pb})$ or chromium $(\mathrm{Cr})$ in the hydrothermal growth solution, and thus in the $\mathrm{ZnO}$ band gap [44,45], or the synthesis of $\mathrm{ZnO}$ composites with other semi-conductors [5].

In our work, we studied the modification of $\mathrm{ZnO}$ with carbon. According to the literature, the addition of carbon can be done by several routes, such as nanocomposites synthesis [46-48], surface modification by adsorption and calcination of carbonaceous species on the surface of the as-grown ZnO NSs [49,50], and carbon introduction in the $\mathrm{ZnO}$ lattice by adding carbonaceous species during the synthesis of the NSs [51,52]. To introduce carbon in the $\mathrm{ZnO}$ lattice, the $\mathrm{Zn}\left(\mathrm{NO}_{3}\right)_{2}$ salt was replaced by $\mathrm{Zn}(\mathrm{Ac})_{2}$ in the hydrothermal growth solution (Figure 2a). SEM observations showed the good distribution of $\mathrm{ZnO} N W s$ grown with nitrate zinc salt $(\mathrm{ZnO}-\mathrm{N})$ with a diameter of $50 \pm 7 \mathrm{~nm}$, a length of $1.79 \pm 0.10 \mu \mathrm{m}$ and a density of $\sim 3 \times 10^{9} \mathrm{NWs} / \mathrm{cm}^{2}$. A good distribution of NWs grown with acetate zinc salt ( $\mathrm{ZnO}-\mathrm{A})$ was also observed with a diameter of $65 \pm 8 \mathrm{~nm}$, a length of $2.655 \pm 0.1 \mu \mathrm{m}$ and a density of $\sim 2 \times 10^{9} \mathrm{NWs} / \mathrm{cm}^{2}$ (Figure 5a). As morphology investigation revealed, $\mathrm{ZnO}-\mathrm{A}$ NWs are larger and longer than $\mathrm{ZnO}-\mathrm{N}$ NWs. In accordance with the literature, an impact of the counter ion used is observed [53]. The use of zinc acetate salt for NWs growth enhances the capping effect, inhibits the rates dissolution and aids the aging and growth of the $\mathrm{ZnO}$ NWs [54]. Indeed, acetate ions will be selectively adsorbed during the growth and the intercalation will extend the NWs along the c-axis [48,55]. Gap measurements suggested the acetate ions adsorbed during the growth and post-annealing seem to contribute to the $\mathrm{ZnO}$ band gap reduction (3.18 eV against $3.21 \mathrm{eV}$ ) [56].

As already mentioned, another studied strategy was to dope $\mathrm{ZnO}$ with transition metals. This strategy is based on the addition of transition metal ions in the growth solution. In short, the samples are synthesized by a simple hydrothermal method, already described in Figure 2a, with a growth solution containing $1.125 \mathrm{mM}$ of $\mathrm{Zn}\left(\mathrm{NO}_{3}\right)_{2}, 0.5625 \mathrm{mM}$ of HMTA and the appropriate quantity of the doping solution ( $\mathrm{FeCl} 3, \mathrm{AgNO} 3$ or $\left.\mathrm{Co}\left(\mathrm{NO}_{3}\right)_{2}\right)$ to obtain a molar percentage of $1 \%, 2 \%$, or $3 \%$ in dopant product [44,45]. SEM study showed quite homogeneous $\mathrm{ZnO}$ NWs arrays for all $\mathrm{Fe}$ and Co doped samples with aspect ratios and morphologies similar to those of the undoped samples (Figure 5b). The Ag-doped samples exhibited a dependence on the dopant concentration, leading to larger and smaller NWs with an increase in Ag\% (Figure 5c). Concerning the gap values, the band gaps decrease with the increasing dopant quantity $(3.10 \mathrm{eV}$ against $3.21 \mathrm{eV})$.

Unfortunately, this method, for which the efficiency was already demonstrated [44,45], could not be applied on construction materials due to possible interactions between the non-conventional substrate and the dopant ions, which could have an adverse effect on the photocatalytic efficiency under natural sunlight [22]. Thus, for this application, a post-grown $\mathrm{ZnO}$ co-catalyst synthesis was developed to reduce the contact between the substrate and the doping solution, and thus avoid any interaction between them. The Fe(III) ion was selected to improve the $\mathrm{ZnO}$ NWs light-absorption and photocatalytic activity, owing to its low-cost, relatively eco-friendly properties and previous results [45]. The Fe(III) solution was dropped on $\mathrm{ZnO} N W$ s grown onto $\mathrm{Si}(\mathrm{ZnO}-\mathrm{A})$, as described in Figure 2a, then dried and calcinated to fix the iron oxide on the surface of $\mathrm{ZnO} N W s$. A volume of 
$69.8 \mu \mathrm{L}$ of $\mathrm{Fe}\left(\mathrm{NO}_{3}\right)_{3}$, whose iron concentration range is included between $8.9 \times 10^{-9} \mathrm{~mol}$ and $4.5 \times 10^{-7} \mathrm{~mol}$, was applied on the sample surface before a drying at $50{ }^{\circ} \mathrm{C}$ for $30 \mathrm{~min}$ in an oven. Finally, the sample was annealed at $350^{\circ} \mathrm{C}$ for $1 \mathrm{~h}$ in ambient atmosphere to convert and fix the iron oxide on the $\mathrm{ZnO}$ surface $\left(\mathrm{ZnO} / \mathrm{Fe}_{\mathrm{x}} \mathrm{O}_{\mathrm{y}}\right)$. This co-catalyst synthesis has shown its effectiveness to extend the range of absorbed light thanks to the deposition of iron oxide on $\mathrm{ZnO} N W s$ as it leads to a decrease of the gap value from $3.27 \mathrm{eV}$ to $3.14 \mathrm{eV}$ and higher visible light absorption [22]. XRD works did not permit to determine the iron oxide phase, but by drawing parallel with literature [57,58], strong assumptions on the $\mathrm{FeOOH}$ and $\mathrm{Fe}_{2} \mathrm{O}_{3}$ combined presence were made. SEM observations demonstrated a non-homogeneous deposition of iron oxide and, thus, the need of improving the deposition process (Figure 5d) [22].
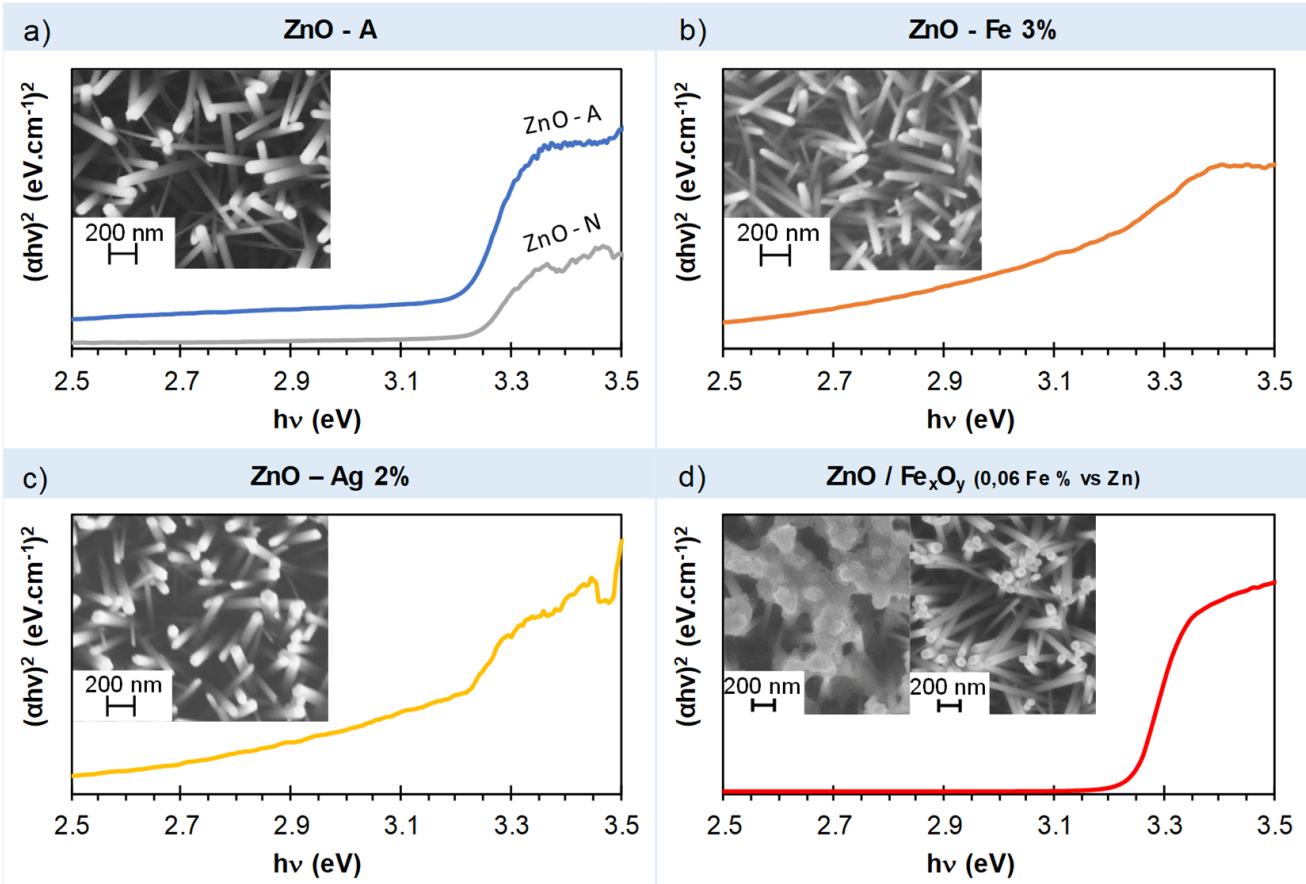

Figure 5. UV-visible spectral plots with Tauc-Lorentz model and SEM images of different modified $\mathrm{ZnO} \mathrm{NWs}$ : ZnO-A (a), $\mathrm{ZnO}-\mathrm{Fe} 3 \%$ (b), $\mathrm{ZnO}-\mathrm{Ag} 2 \%$ (c), and $\mathrm{ZnO} / \mathrm{Fe}_{\mathrm{x}} \mathrm{O}_{\mathrm{y}}(0.06 \mathrm{Fe} \%$ vs $\mathrm{Zn}$ ), (d) respectively.

\section{Photocatalysis for Water Purification}

The photocatalytic performances of these developed materials were proved for the photodegradation of model organic molecules commonly used in the pharmaceutical, food and textile industries. The selected molecules were three organic dyes: acid red 14 (AR14), methylene blue (MB), and methyl orange (MO). The different dye solutions had an initial concentration of $10 \mu \mathrm{M}$. Samples of $\mathrm{ZnO}$-decorated civil engineering materials were immersed into $30 \mathrm{~mL}$ of dye-contaminated aqueous solution and irradiated with a UV lamp (Hamamatsu LC $8,4500 \mathrm{~mW} / \mathrm{cm}^{2}, \lambda=365 \mathrm{~nm}$ ) under magnetic stirring. The photocatalytic process was monitored by UV-visible spectrophotometry every $15 \mathrm{~min}$ for $3 \mathrm{~h}$ and the degradation efficiency $X(\%)$ was estimated thanks to Equation (6):

$$
X(\%)=\frac{\mathrm{A}_{0}-\mathrm{A}}{\mathrm{A}_{0}} \times 100
$$

where $\mathrm{A}_{0}$ and $\mathrm{A}$, respectively, stand for the initial and actual absorption peak values at the wavelength of the maximum absorption for the studied dye $\left(\lambda_{\max }=665 \mathrm{~nm}\right.$ for MB, $515 \mathrm{~nm}$ for AR14, and $464 \mathrm{~nm}$ for MO). All Si-functionalized samples and functionalized civil engineering materials demonstrated their ability to degrade the three selected organic 
dyes in less than $3 \mathrm{~h}[22-24,28]$. MO, the most difficult to degrade of our model pollutants due to its stability, was degrade more slowly ( 105 min) than MB and AR14 ( 90 min). The recyclability of the samples was also proved with no losses of efficiency after 5 cycles of uses [28].

Depending on the growth conditions, either $\mathrm{C} 1$ or $\mathrm{C} 2$ (Section 2.1), $\mathrm{ZnO}-\mathrm{N}$ grown on silicon demonstrated different efficiencies (Figure 6a). These differences can be assigned to the bigger $\mathrm{ZnO}-\mathrm{C} 2$ surface area. The same should explain the higher photocatalytic activity of functionalized tiling and concrete samples after $4 \mathrm{~h}$ of hydrothermal growth. Indeed, the silicon substrate area is around $2.25 \mathrm{~cm}^{2}$ and the civil engineering material substrate areas are around $6.25 \mathrm{~cm}^{2}$. Larger photocatalytic differences could be expected in regard to the surface areas difference. The weak gap in efficiency could be explained by the non-optimal agitation and reactor for civil engineering materials. Then, the photocatalytic efficiency of functionalized tiling and concrete samples were improved for AR14 degradation by reducing its growth time synthesis [29].
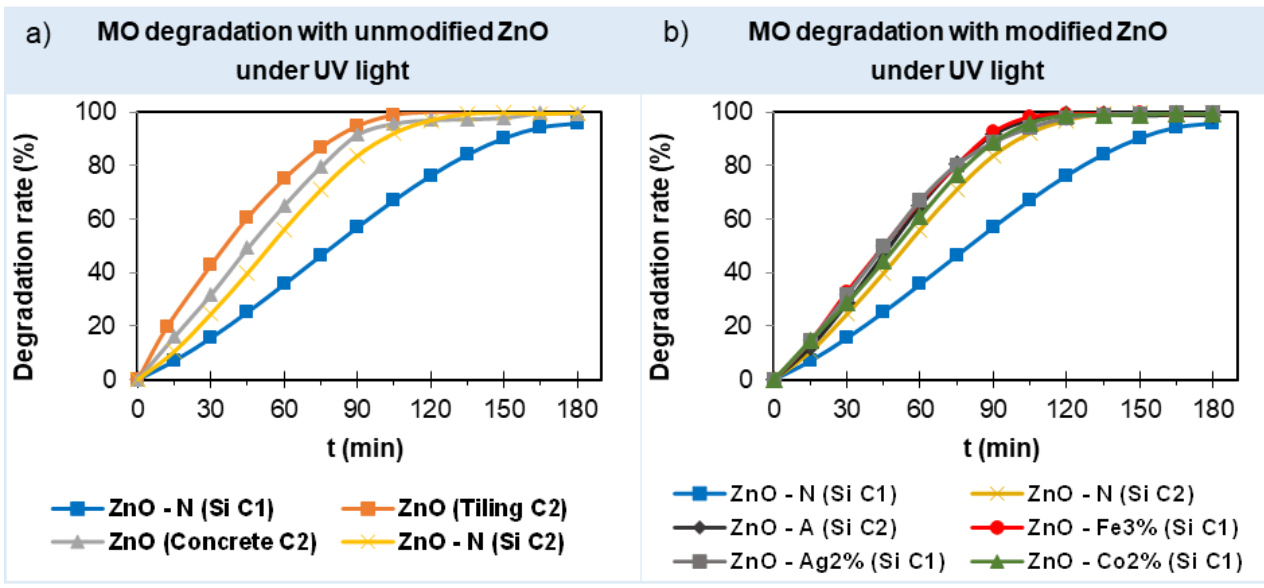

Figure 6. MO degradation with unmodified (a) and modified (b) $\mathrm{ZnO}$ grown onto different substrates under UV light $\left(\sim 365 \mathrm{~nm}, \mathrm{I}_{\text {received by the sample }}=35 \mathrm{~mW} / \mathrm{cm}^{2}\right)$.

Previous results on $\mathrm{ZnO}$ grown in the conditions $\mathrm{C} 1$ demonstrated that all doped samples showed better efficiency than undoped samples, the most efficient for each dopant being the $\mathrm{ZnO}$ doped with $3 \%$ of $\mathrm{Fe}(\mathrm{ZnO}-\mathrm{Fe} 3 \%)$, and $2 \%$ of $\mathrm{Ag}$ or $\mathrm{Co}(\mathrm{ZnO}-\mathrm{Ag} 2 \%$ and $\mathrm{ZnO}-\mathrm{Co} 2 \%$ ) [44]. The photocatalytic efficiency enhancement (Figure 6b) can be attributed to two effects: the reduction of the band-gap energy, allowing more photons to be absorbed; and the reduced electron-hole recombination rate, thanks to the increase in oxygen vacancies and to the dopant ions on the NWs surface. Similar results were obtained with $\mathrm{ZnO}-\mathrm{A}(\mathrm{C} 2)$ samples, which efficiency is better than the one of the $\mathrm{ZnO}-\mathrm{N}$ ( $\mathrm{C} 1$ and $\mathrm{C} 2$ ) samples, demonstrating the efficiency of the modification of $\mathrm{ZnO}$ strategies to increase the photocatalytic efficiency of the samples.

Then, the photocatalytic performances of these optimal functionalized samples were proved for dye photodegradation under natural sunlight. Under sunny weather, MB and AR14 were fully degraded in $4 \mathrm{~h}$ over the optimal concrete sample and were removed from water with degradation rates of $98 \%$ and $60 \%$ for the tiling optimal sample. MO, which is the most difficult dye to degrade, was degraded at $82 \%$ and $58 \%$ over concrete and tiling samples, respectively, in the same conditions [29]. Cloudy weather leads to a slight decrease in the efficiency with the lowered UV intensity received by the samples, but still offers excellent photocatalytic activity. In a previous study [22], the efficiency of the $\mathrm{ZnO}$ /iron oxide samples was also evaluated and proved for the $\mathrm{MO}$ photodegradation under natural sunlight. Modifying the $\mathrm{ZnO}$ with an optimal ratio of $0.06 \%$ of iron (Fe vs. $\mathrm{Zn} \mathrm{M}$ ) improved the photocatalytic efficiency under natural sunlight with an increase of $11 \%$ of the $\mathrm{MO}$ degradation, compared to the reference $\mathrm{MO}$ degradation with $\mathrm{ZnO}$, after $5 \mathrm{~h}$ of irradiation with no iron leaching [22]. 
In parallel to these experiments, the photocatalytic efficiency of the ZnO-NSs-based microfluidic reactors - for which production was described in Section 2.3-was proved by degrading continuous streams of water polluted with AR14, under UV irradiation (Figure 7). The obtained results lead to the determination of the optimal synthesis parameters for the best photocatalytic efficiency $\left(200 \mu \mathrm{L} \cdot \mathrm{min}^{-1}, 80^{\circ} \mathrm{C}, 1 \mathrm{~h}\right)$. Thanks to these NSs-based microfluidic reactor, a $98 \%$ photodegradation rate was reached after 4 passes in the reactor, which is roughly equivalent to $40 \mathrm{~s}$ of UV light irradiation [30]. In this same work, the photocatalysis flow rate influence was studied, and while the optimum was observed at $200 \mu \mathrm{L} \cdot \mathrm{min}^{-1}$, very good results were obtained when the flowrate was increased to $500 \mu \mathrm{L} \cdot \mathrm{min}^{-1}$ (more than $80 \%$ of degradation obtained in 5 passes, thus, $50 \mathrm{~s}$ of irradiation). These results are highly encouraging in the aim of designing high flowrate microreactors.

a)

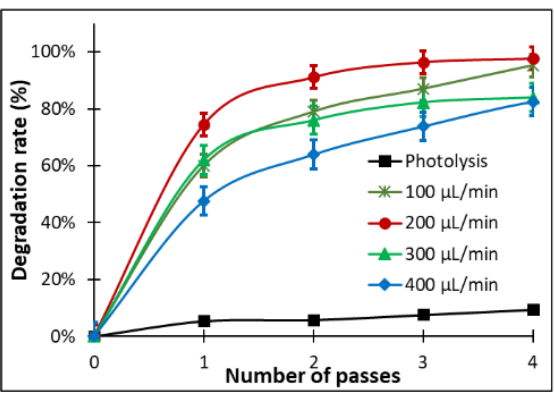

c)

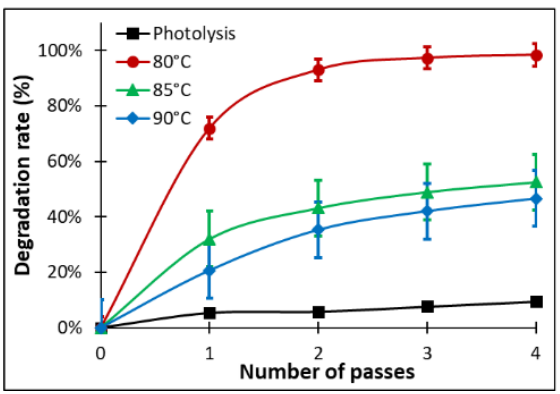

b) Effect of the growth time
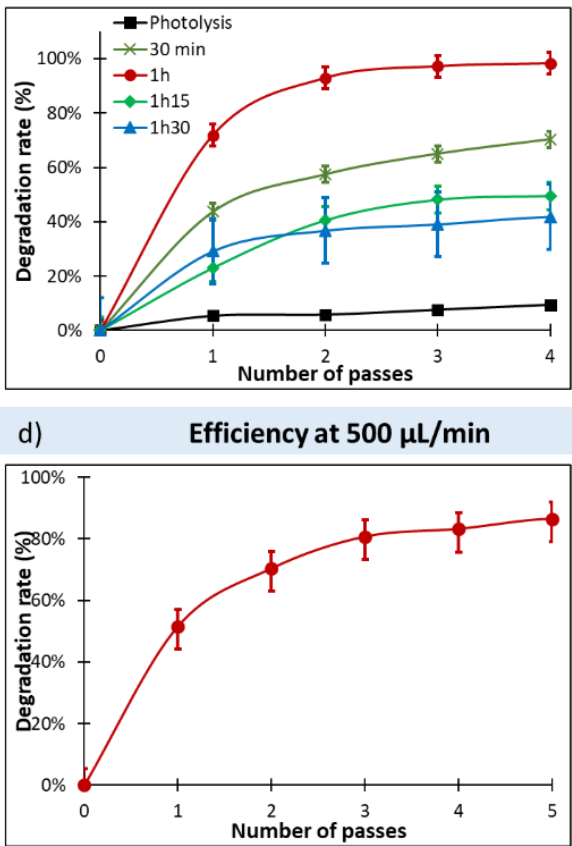

Figure 7. Effect of the different growth conditions (a) flowrate, (b) growth time and (c) growth temperature and effect of the augmentation of the photocatalysis flowrate (d) on the photocatalytic efficiency of the samples for AR14 degradation under UV light ( 365 nm, Ireceived by the sample $=35 \mathrm{~mW} / \mathrm{cm}^{2}$, reproduced from [30] with permission of the Royal Society of Chemistry).

Thus, these results imply that ZnO NSs could be used on different substrates and under different modes for environmental remediation by photocatalysis under UV light and natural sunlight, with no particular need to dope or modify the ZnO NSs. Nevertheless, modified $\mathrm{ZnO}$ led to an improved photocatalytic efficiency.

\section{HPLC-MS Analysis and Comparison with UV-Visible Results}

The photocatalytic results presented in the previous parts were obtained by UV-visible spectroscopy. This kind of analysis is very efficient to quickly estimate the degradation rate of the pollutants but does not give any information on the degradation mechanism or on the remaining compounds in the effluent solution. This could lead to considering effluents in which dangerous compounds remain as safe. Thus, a more sensitive analytic method is required to ensure the harmlessness of the effluents.

High-Performance Liquid Chromatography coupled with Mass Spectrometry (HPLCMS) is a very powerful method [59], widely used in the detection and quantification of several different compounds. This method is, for example, used to detect active compounds in medicinal herbs [60], or to identify medicaments that are new [61,62] or counterfeit [63]. 
However, it requires much more preparation and more expensive equipment than UVvisible spectrometry.

We already followed the degradation of $\mathrm{BM}$ by $\mathrm{ZnO}$ NWs samples, synthesized under the conditions $\mathrm{C} 1$ (see Section 2.1), by UV-visible spectroscopy and by HPLC-MS analysis in our previous work [24]. We found that, even if MB absorbance reaches zero, HPLC-MS is still able to detect MB in the effluents, and that the concentrations calculated from UVvisible spectroscopy are lower than the ones obtained from the HPLC-MS results. However, according to the two different methods, even if there is still MB in the effluents at the end of the photodegradation, the final effluents are safe for humans, in regard to their MB concentration $\left(14 \mu \mathrm{g} \cdot \mathrm{L}^{-1}\right)$, and proving that the photocatalytic degradation by $\mathrm{ZnO} N W s$ is an efficient method to purify water from organic pollutants.

In light of the results obtained with $\mathrm{MB}$, we performed the same experimental protocol on AR14, still following the degradation by UV spectroscopy and HPLC-MS. The UV-visible results are presented in Figure 8a, and showed a degradation rate of $95 \%$ after $90 \mathrm{~min}$, and a degradation rate higher than $99 \%$ after $135 \mathrm{~min}$. The mobile phase composition of the HPLC-MS analysis was adapted from literature [64], and the HPLC-MS parameters are summarized in Table 1.
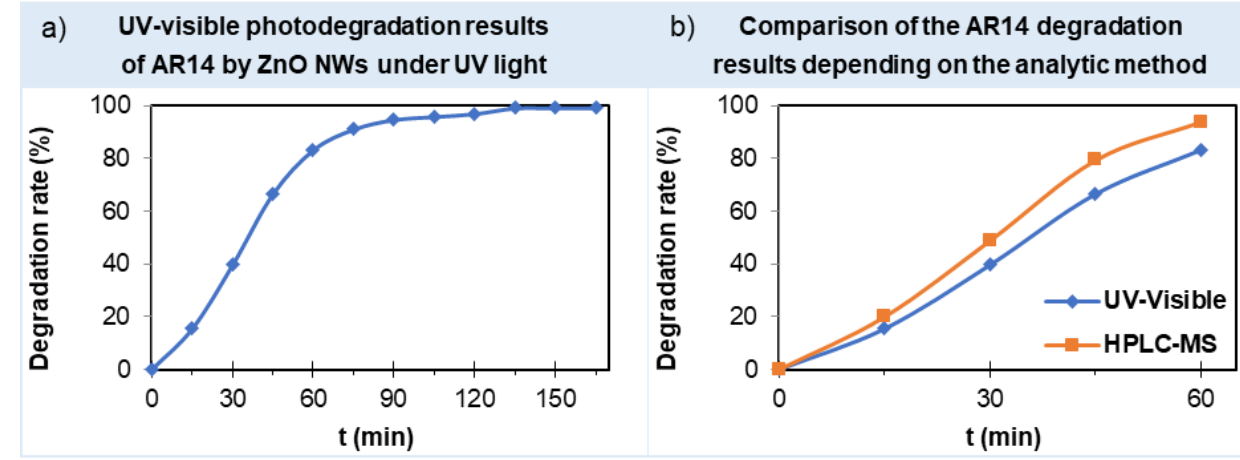

Figure 8. (a) UV-visible photodegradation results of AR14 by ZnO NWs (grown conditions (1), $4 \mathrm{~h}$, $90^{\circ} \mathrm{C}$ ) under UV light and (b) comparison of the AR14 degradation results depending on the analytic method (UV light: $\sim 365 \mathrm{~nm}, \mathrm{I}_{\text {received by the sample }}=35 \mathrm{~mW} / \mathrm{cm}^{2}$ ).

Table 1. HPLC-MS parameters of the analysis of AR14.

\begin{tabular}{|c|c|}
\hline & HPLC \\
\hline Mobile phase & $\begin{array}{l}\text { Acetonitrile } 20 \% \text { (volumic) } \\
\text { Aqueous ammonium acetate }(0.05 \mathrm{M}) 80 \% \text { (volumic) }\end{array}$ \\
\hline Flowrate & $0.2 \mathrm{~mL} \cdot \mathrm{min}^{-1}$ \\
\hline Injection volume & $20 \mu \mathrm{L}$ \\
\hline \multicolumn{2}{|c|}{ Mass spectrometer } \\
\hline Polarity & Negative \\
\hline Frequency & Extended Dynamic Range $2 \mathrm{GHz}$ \\
\hline Mass range & $50-1700 \mathrm{~m} / \mathrm{z}$ \\
\hline
\end{tabular}

Examining the AR14 degradation by HPLC-MS showed the disappearance of both the AR14 chromatography and MS peaks after 90 min under UV light. The HPLC-MS results could only be used for the calculation of the remaining AR14 concentration for the first $60 \mathrm{~min}$, as the AR14 detection decreased below the quantification limit of the device after that time stamp. The obtained results are presented in Table 2. 
Table 2. HPLC-MS photodegradation results of AR 14 by ZnO NWs under UV light.

\begin{tabular}{cccc}
\hline Time (min) & $\boldsymbol{m} / \boldsymbol{z} \mathbf{2 8 8}$ Peak Area & $\begin{array}{c}\text { Calculated } \\
\text { Concentration }(\boldsymbol{\mu M})\end{array}$ & $\begin{array}{c}\text { Calculated } \\
\text { Degradation Rate }\end{array}$ \\
\hline 0 & $2,963,405$ & 8.59 & $0 \%$ \\
15 & $2,370,033$ & 6.87 & $20.02 \%$ \\
40 & 151,015 & 4.38 & $49.01 \%$ \\
60 & 605,947 & 1.76 & $79.55 \%$ \\
\end{tabular}

Comparing the results obtained from HPLC-MS and from the UV-vis demonstrates that, conversely to what was observed for MB, HPLC-MS seems to overestimate the degradation results. This could be due to the parasitic molecules we detected in the reaction mix, which could be increasing the absorbance of the reaction mix, thus decreasing the degradation rate calculated from the UV-visible results. The comparison curves of the two results are shown in Figure 8b.

Unfortunately, no degradation product was identified in the reaction mix, and we could not provide a degradation mechanism for the degradation of AR14. This might be due to a variety of factors, such as the short lifespan of the degradation products, making them disappear before the analysis, or their quantity being too low to be detected even by the HPLC. However, we could calculate the concentration of AR14 in the reaction mix after $60 \mathrm{~min}$, and found it to be of $0.51 \mu \mathrm{M}$, which corresponds to $254 \mu \mathrm{g} \cdot \mathrm{L}^{-1}$. Considering the degradation continues for 105 more minutes, we can make the hypothesis that the actual final concentration will be even lower than $254 \mu \mathrm{g} \cdot \mathrm{L}^{-1}$.

It is still possible to compare the concentration we calculated after $60 \mathrm{~min}$ to the safety limits recommended by literature and governments. In the EU, the quantity of AR14 in food and drinks must stay in the $50-500 \mathrm{mg} \cdot \mathrm{L}^{-1}$ interval, depending on the considered food and drink types [65]. According to the AR14 Safety Data Sheet, its toxicity threshold for algae is $34.82 \mathrm{mg} \cdot \mathrm{L}^{-1}$ for 3 days. Finally, chronic toxicity is reached with a concentration of $1 \%$ AR14 in water [66]. Thus, with their calculated concentration of $254 \mu \mathrm{g} \cdot \mathrm{L}^{-1}$, we can state that our effluents are safe, both for humans and for the environment.

\section{Conclusions}

This work is a review of our previous works on the development of ZnO NSs-based photocatalyst materials by hydrothermal synthesis and their photocatalytic activity for organic dyes removal. Firstly, the universality and the feasibility of the synthesis method were presented from the initial Si substrates to non-conventional substrates such as civil engineering materials, allowing for the obtaining of ZnO NSs with gap values from $3.18 \mathrm{eV}$ to $3.23 \mathrm{eV}$ and $\mathrm{ZnO}$ Wurtzite $\mathrm{XRD}$ peaks. In this section, a short summary on microfluidic cells development and their main results are also presented. Strategies developed to reduce the $\mathrm{ZnO}$ band gap and improve its photocatalytic efficiency are also introduced by demonstrating how modifying $\mathrm{ZnO}$ with carbon, doping $\mathrm{ZnO}$ with transition metal ions, and synthesizing $\mathrm{ZnO} /$ iron oxide co-catalyst via simple processes are easily adaptable to the industry, improving the photodegradation efficiency. Then, this paper displayed the photocatalytic results of the different kinds of samples under classic and microfluidic modes, and under UV and solar light, for the degradation of MO, AR14 and MB. Excellent results were obtained with a total degradation of the three dyes after $3 \mathrm{~h}$ under UV light, as well as very promising results under natural sunlight, even on cloudy days. Furthermore, the effect of the used substrates and the growth conditions on the kinetics and efficiency of the photodegradation were discussed. Lastly, this paper investigated the photodegradation results obtained with HPLC-MS for MB and AR 14, by comparing them with the UV-visible results, and used the previous method to demonstrate that the final effluents after the degradation are safe for humans and the environment. 


\begin{abstract}
Author Contributions: M.L.P.: Conceptualization, Methodology, Investigation, Formal analysis, Writingoriginal draft, Validation; N.M.: Methodology, Investigation, Formal analysis, Writing-original draft; Y.L.-W.: Conceptualization, Supervision, Validation, Project administration. All authors have read and agreed to the published version of the manuscript.
\end{abstract}

Funding: This research received no external funding.

Institutional Review Board Statement: Not applicable.

Informed Consent Statement: Not applicable.

Data Availability Statement: The study did not report any data.

Conflicts of Interest: The authors declare no conflict of interest.

\title{
References
}

1. Corcoran, E.; Nellemann, C.; Baker, E.; Bos, R.; Osborn, D.; Savelli, H. Sick Water? The Central Role of Wastewater Management in Sustained Development; UN-HABITAT, GRID-Arendal; United Nations Environment Programme: Nairobi, Kenya, 2010; pp. 1-88.

2. World Economic Forum. The Global Risks Report, 11th ed.; WEF: Cologny, Switzerland, 2016; pp. 1-103.

3. Singh, V.P.; Sandeep, K.; Kushwaha, H.S.; Powar, S.; Vaish, R. Photocatalytic, Hydrophobic and antimicrobial characteristics of $\mathrm{ZnO}$ nano needle embedded cement composites. Construct. Build. Mater. 2018, 185, 285-294. [CrossRef]

4. Lee, K.M.; Lai, C.W.; Ngai, K.S.; Ruan, J.C. Recent developments of zinc oxide based photocatalyst in water treatment technology: A review. Water Res. 2016, 88, 428-448. [CrossRef] [PubMed]

5. Liu, Y.; Yu, L.; Hu, Y.; Guo, C.; Zhang, F.; Lou, X.W. A magnetically separable photocatalyst based on nest-like $\gamma-\mathrm{Fe}_{2} \mathrm{O}_{3} / \mathrm{ZnO}$ double-shelled hollow structures with enhanced photocatalytic activity. Nanoscale 2012, 4, 183-187. [CrossRef] [PubMed]

6. Sun, C.; Xu, Q.; Xie, Y.; Ling, Y.; Hou, Y. Designed synthesis of anatase- $\mathrm{TiO}_{2}$ (B) biphase nanowire/ZnO nanoparticle heterojunction for enhanced photocatalysis. J. Mater. Chem. 2018, 6, 8289-8298. [CrossRef]

7. Gosh, S.; Amoin Kouame, N.; Remita, S.; Ramos, L.; Goubard, F.; Aubert, P.H.; Dazzi, A.; Deniset-Besseau, A.; Remita, H. Visible-light active conducting polymer nanostructures with superior photocatalytic activity. Sci. Rep. 2015, 5, 18002. [CrossRef]

8. Chen, F.; Liu, H.; Bagwasi, S.; Shen, X.; Zhang, J. Photocatalytic study of BiOCl for degradation of organic pollutants under UV irradiation. J. Photochem. Photobiol. A Chem. 2010, 215, 76-80. [CrossRef]

9. Manthina, V.; Agrios, A.G. Single-pot ZnO nanostructure synthesis by chemical bath deposition and their applications. NanoStruct. Nano-Objects 2016, 7, 1-11. [CrossRef]

10. Wojnarowicz, J.; Chudoba, T.; Lojkowski, W. A Review of Microwave Synthesis of Zinc Oxide Nanomaterials: Reactants, Process Parameters and Morphologies. Nanomaterials 2020, 10, 1086. [CrossRef]

11. Noman, M.T.; Amor, N.; Petru, M. Synthesis and applications of ZnO nanostructures (ZONSs): A review. Crit. Rev. Solid State Mater. Sci. 2021, 1-43. [CrossRef]

12. Le Pivert, M.; Kerivel, O.; Zerreli, B.; Leprince-Wang, Y. ZnO nanostructures based innovative photocatalytic road for air purification. J. Clean. Prod. 2021, 318, 128447. [CrossRef]

13. Qiu, Y.; Wang, L.; Xu, L.; Shen, Y.; Wang, L.; Liu, Y. Shaped-controlled growth of sphere-like ZnO on modified polyester fabric in water bath. Mater. Lett. 2021, 288, 129342. [CrossRef]

14. Choudhary, S.; Sahu, K.; Bisht, A.; Satpati, B.; Mohapatra, S. Rapid synthesis of ZnO nanowires and nanoplates with highly enhanced photocatalytic performance. Appl. Surf. Sci. 2021, 541, 148484. [CrossRef]

15. Zhang, Y.; Huang, X.; Yeom, J. A flotable piezo-photocatalytic platform based on semi-embedded ZnO nanowire array for high-performance water decontamination. Nano-Micro Lett. 2019, 11, 11. [CrossRef]

16. Hossain, M.F.; Naka, S.; Okada, H. Fabrication of perovskite solal cells with ZnO nanostructures prepared on seedless ITO substrate. J. Mater. Sci. Mater. Elec. 2018, 29, 13864-13871. [CrossRef]

17. Vayssieres, L. Growth of Arrayed Nanorods and Nanowires of ZnO from Aqueous Solutions. Adv. Mater. 2003, 15, 464-466. [CrossRef]

18. Vayssieres, L.; Keis, K.; Lindquist, S.E.; Hagfeldt, A. Purpose-Built Anisotropic Metal Oxide Material: 3D Highly Oriented Microrod Array of ZnO. J. Phys. Chem. B 2001, 105, 3350-3352. [CrossRef]

19. Bao, Y.; Wang, C.; Ma, J.Z. Morphology control of ZnO microstructures by varying hexamethylenetetramine and trisodium citrate concentration and their photocatalytic activity. Mater. Des. 2016, 101, 7-15. [CrossRef]

20. McPeak, K.M.; Le, T.P.; Britton, N.G.; Nickolov, Z.S.; Elabd, Y.A.; Baxter, J.B. Chemical Bath Deposition of ZnO Nanowires at Near-Neutral pH Conditions without Hexamethylenetetramine (HMTA): Understanding the Role of HMTA in ZnO Nanowire Growth. Langmuir 2011, 27, 3672-3677. [CrossRef]

21. Greene, L.E.; Yuhas, B.D.; Law, M.; Zitoun, D.; Yang, P. Solution-grown Zinc oxide nanowires. Inorg. Chem. 2006, 45, 735-7543. [CrossRef]

22. Le Pivert, M.; Suo, H.; Tang, G.; Qiao, H.; Zhao, Z.; Martin, N.; Liu, C.; Leprince-Wang, Y. Improving natural sunlight photocatalytic efficiency of $\mathrm{ZnO}$ nanowires decorated by iron oxide cocatalyst via a simple drop method. Mater. Chem. Phys. 2022, 275, 125304. [CrossRef]

23. Habba, Y.G.; Capochichi-Gnambodoe, M.; Serairi, L.; Leprince-Wang, Y. Enhanced photocatalytic activity of ZnO nanostructure for water purification. Phys. Status Solidi B 2016, 253, 1480-1484. [CrossRef] 
24. Martin, N.; Leprince-Wang, Y. HPLC-MS and UV-Visible Coupled Analysis of Methylene Blue Photodegradation by Hydrothermally Grown ZnO Nanowires. Phys. Status Solidi A 2021, 218, 2100532. [CrossRef]

25. Fathy, A.; Le Pivert, M.; Kim, Y.J.; Ba, M.O.; Erfan, M.; Sabry, Y.M.; Khalil, D.; Leprince-Wang, Y.; Bourouina, T.; GnambodoeCapochichi, M. Continuous Monitoring of Air Purification: A Study on Volatile Organic Compounds in a Gas Cell. Sensors 2020, 20, 934. [CrossRef] [PubMed]

26. Tian, J.-H.; Hu, H.; Li, S.-S.; Zhang, F.; Liu, J.; Shi, J.; Li, X.; Tian, Z.-Q.; Chen, Y. Improved seedless hydrothermal synthesis of dense and ultralong ZnO nanowires. Nanotechnol. 2011, 22, 245601. [CrossRef]

27. Gao, L. A Dual Approach for Water Purification Based on Solar Energy. Ph.D. Thesis, Degree-Granting Gustave Eiffel University, Paris, France, 2022.

28. Le Pivert, M.; Poupart, R.; Capochichi-Gnambodoe, M.; Martin, N.; Leprince-Wang, Y. Direct growth of ZnO nanowires on civil engineering materials: Smart materials for supported photodegradation. Microsyst. Nanoengin. 2019, 5, 57. [CrossRef]

29. Le Pivert, M.; Zerelli, B.; Martin, N.; Capochichi-Gnambodoe, M.; Leprince-Wang, Y. Smart ZnO decorated optimized engineering materials for water purification under natural sunlight. Construct. Build. Mater. 2019, 257, 119592. [CrossRef]

30. Martin, N.; Lacour, V.; Perrault, C.M.T.; Roy, E.; Lerince-Wang, Y. High flow rate microreactors integrating in situ grown ZnO nanowires for photocatalytic degradation. React. Chem. Eng. 2022, 1-8. [CrossRef]

31. Pastor, A.; Balbuena, J.; Cruz-Yusta, M.; Pavlovic, I.; Schànchez, L. ZnO on rice husk: A sustainable photocatalyst for urban air purification. Chem. Eng. J. 2019, 368, 659-667. [CrossRef]

32. Abdulrahman, A.F.; Ahmed, S.M.; Hamad, S.M.; Almessiere, M.A.; Ahmed, N.M.; Sadaji, S.M. Effect of different pH values on growth solutions for the ZnO nanostructures. J. Phys. 2021, 71, 175-189. [CrossRef]

33. Khoa, N.T.; Kim, S.W.; Thuan, D.V.; Yoo, D.H.; Kim, E.J.; Hahn, S.H. Hydrothermally controlled ZnO nanosheet self-assembled hollow spheres/hierarchical aggreagates and their photocatalytic activities. CrystEngComm 2013, 16, 1344-1350. [CrossRef]

34. Samadi, M.; Shivaee, H.A.; Pourjavadi, A.; Moshfegh, A.Z. Synergism of oxygen vacancy and carbonaceous species on enhanced photocatalytic activity of electrospun $\mathrm{ZnO}$-carbon nanofibers: Charge carrier scavengers mechanism. Appl. Catal. A Gen. 2013, 466, 153-160. [CrossRef]

35. Yu, Z.; Moussa, H.; Liu, M.; Schneider, R.; Moliere, M.; Liao, H. Solution precursor plasma spray process as an alternative rapid one-step route for the development of hierarchical $\mathrm{ZnO}$ films for improved photocatalytic degradation. Ceram. Int. 2018, 44, 2085-2092. [CrossRef]

36. Erfan, M.; Gnambodoe-Capochichi, M.; Sabry, Y.M.; Khalil, D.; Leprince-Wang, Y.; Bourouina, T. Spatiotemporal dynamics of nanowire growth in a microfluidic reactor. Microsyst. Nanoeng. 2021, 7, 77. [CrossRef]

37. McPeak, K.M.; Baxter, J.B. ZnO Nanowires Grown by Chemical Bath Deposition in a Continuous Flow Microreactor. Cryst. Growth. Des. 2009, 9, 4538-4545. [CrossRef]

38. He, Z.; Li, Y.; Zhang, Q.; Wang, H. Capillary microchannel-based microreactors with highly durable $\mathrm{ZnO} / \mathrm{TiO}_{2}$ nanorod arrays for rapid, high efficiency and continuous-flow photocatalysis. Appl. Catal. B 2010, 93, 376-382. [CrossRef]

39. McPeak, K.M.; Baxter, J.B. Microreactor for High-Yield Chemical Bath Deposition of Semiconductor Nanowires: ZnO Nanowire Case Study. Ind. Eng. Chem. Res. 2009, 48, 5954-5961. [CrossRef]

40. Wang, N.; Zhang, X.; Wang, Y.; Yu, W.; Chan, H.L.W. Microfluidic reactors for photocatalytic water purification. Lab Chip 2014, 14, 1074-1082. [CrossRef]

41. Cargou, S. Dispositif Fluidique D'assainissement d'un Fluide et Procédé D'assainissement Associé. Patent number WO2019/053219, 21 March 2019.

42. Dash, P.; Manna, A.; Mishra, N.C.; Varma, S. Synthesis and characterization of aligned ZnO nanorods for visible light photocatalysis. Physica E 2019, 107, 38-46. [CrossRef]

43. Bora, T.; Sathe, P.; Laxman, K.; Dobrestov, S.; Dutta, J. Defect engineered visible light active ZnO nanorods for photocatalytic treatment of water. Catal. Today 2017, 284, 11-18. [CrossRef]

44. Martin, N.; Capochichi-Gnambodoe, M.; Le Pivert, M.; Leprince-Wang, Y. A Comparative Study on the Photocatalytic Efficiency of ZnO Nanowires Doped by Different Transition Metals. Acta Phys. Pol. 2019, 135, 471-474. [CrossRef]

45. Habba, Y.G.; Capochichi-Gnambodoe, M.; Leprince-Wang, Y. Enhanced Photocatalytic Activity of Iron-Doped ZnO Nanowires for Water Purification. Appl. Sci. 2017, 7, 1185. [CrossRef]

46. Chen, Y.C.; Katsumata, K.I.; Chiu, Y.H.; Okada, K.; Matsushita, N.; Hsu, Y.J. ZnO-graphene composites as practical photocatalysts for gaseous acetaldehyde degradation and electrolytic water oxidation. Appl. Catal. A Gen. 2015, 90, 1-9. [CrossRef]

47. Bechambi, O.; Sayadi, S.; Najjar, W. Photocatalytic degradation of bisphenol A in the presence of C-Doped ZnO: Effect of operational parameters and photodegradation mechanism. J. Ind. Eng. Chem. 2015, 32, 201-210. [CrossRef]

48. Liu, X.; Du, H.; Sun, X.W.; Liu, B.; Zhao, D.; Sun, H. Visible-light photoresponse in a hollow microtube-nanowire structure made of carbon-doped ZnO. CrystEngComm 2012, 8, 2886-2890. [CrossRef]

49. Akir, S.; Hamdi, A.; Addad, A.; Coffinier, Y.; Boukherroub, R.; Omrani, A.D. Facile synthesis of carbon-ZnO nanocomposite with enhanced visible light photocatalytic performance. Appl. Surf. Sci. 2017, 400, 461-470. [CrossRef]

50. Chakraborty, P.; Majumder, T.; Dhar, S.; Mondal, S.P. Nonenzymetic glucose sensing using carbon functionalized carbon doped ZnO nanorod arrays. AIP Conf. Proc. 2018, 1942, 050074. [CrossRef]

51. Liu, S.; Li, C.; Yu, J.; Xiang, Q. Improved visible-light photocatalytic activity of porous carbon self-doped ZnO nanosheetassembled flowers. CrystEngComm 2011, 13, 2533-2541. [CrossRef] 
52. Chen, L.C.; Tu, Y.J.; Wang, Y.S.; Kan, R.S.; Huang, C.M. Characterization and photoreactivity of N-, S-, and C- doped ZnO under UV and visible light illumination. J. Photochem. Photobio. A Chem. 2008, 199, 170-178. [CrossRef]

53. Yogamalar, N.R.; Bose, A.C. Tuning the aspect ratio of hydrothermally grown ZnO by choice of precursor. Solidi State Chem. 2011, 184, 12-20. [CrossRef]

54. Govender, K.; Boyle, D.S.; Kenway, P.B.; O'Bien, P. Understanding the factors that govern the deposition and morphology of thin films of $\mathrm{ZnO}$ from aqueous solution. J. Mater. Chem. 2004, 14, 2575-2591. [CrossRef]

55. Akgun, M.C.; Kalay, Y.E.; Unalan, H.E. Hydrothermal zinc oxide nanowire growth using zinc acetate dihydrate salt. J. Mater. Res. 2012, 27, 1445-1451. [CrossRef]

56. Le Pivert, M. Nanostructures de ZnO Pour le Développement de Route Dépolluantes Photocatalytiques. Ph.D. Thesis, DegreeGranting University Paris-Est, Paris, France, 2020.

57. Shi, W.; Gao, T.; Zhang, L.; Ma, Y.; Liu, Z.; Zhang, B. Tailoring the surface structures of iron oxide nanorods to support Au nanoparticles for CO oxidation. Chin. J. Catal. 2020, 40, 1884-1894. [CrossRef]

58. Achouri, F.; Corbel, S.; Aboulaich, A.; Balan, L.; Ghrabi, A.; Ben Said, M.; Schneider, R. Aqueous synthesis and enhanced photocatalytic activity of $\mathrm{ZnO} / \mathrm{Fe}_{2} \mathrm{O}_{3}$ heterostructures. J. Phys. Chem. Solid. 2014, 75, 1081-1087. [CrossRef]

59. Fernandez, C.; Soledad Larrechi, M. An analytical overview of processes for removing organic dyes from wastewater effluents. Trend. Anal. Chem. 2010, 29, 1202-1211. [CrossRef]

60. Steinmann, D.; Ganzera, M. Recent advances on HPLC/MS in medicinal plant analysis. J. Pharm. Biomed. Anal. 2011, 55, 744-757. [CrossRef] [PubMed]

61. Ackermann, B.L.; Berna, M.J.; Murphy, A.T. Recent Advances in use of LC/MS/MS for Quantitative High-Throughput Bioanalytical Support of Drug Discovery. Curr. Top. Med. Chem. 2002, 2, 53-66. [CrossRef]

62. Korfmacher, W.A. Foundation review: Principles and applications of LC-MS in new drug discovery. Drug Discov. Today 2005, 20, 1357-1367. [CrossRef]

63. Martino, R.; Malet-Martino, M.; Gilard, V.; Balayssac, S. Counterfeit drugs: Analytical techniques for their identification. Anal Bioanal. Chem. 2010, 398, 77-92. [CrossRef]

64. Wang, A.; Qu, J.; Liu, H.; Ge, J. Degradation of azo dye Acid Red 14 in aqueous solution by electrokinetic and electrooxidation process. Chemosphere 2004, 55, 1189-1196. [CrossRef]

65. Peksa, V.; Jahn, M.; Stolcova, L.; Schulz, V.; Proska, J.; Prochazka, M.; Weber, K.; Cialla-May, D.; Popp, J. Quantitative SERS Analysis of Azorubine (E 122) in Sweet Drinks. Anal. Chem. 2015, 87, 2840-2844. [CrossRef]

66. European Food Safety Authority. Scientific opinion on the re-evaluation of azorubine/carmoisine (E 122) as a food additive. EFSA J. 2009, 7, 1332. [CrossRef] 